\title{
A Technical Note on Fabrication and Thermal Performance Studies of a Solar Pond Model
}

\author{
Abhishek Saxena ${ }^{1}$ and Varun Goel ${ }^{2}$ \\ ${ }^{1}$ Department of Mechanical Engineering, MIT, Moradabad 244001, India \\ ${ }^{2}$ Department of Mechanical Engineering, NIT, Hamirpur 177001, India \\ Correspondence should be addressed to Abhishek Saxena; culturebeat94@yahoo.com
}

Received 19 December 2012; Accepted 10 February 2013

Academic Editor: Zuhal Oktay

Copyright (C) 2013 A. Saxena and V. Goel. This is an open access article distributed under the Creative Commons Attribution License, which permits unrestricted use, distribution, and reproduction in any medium, provided the original work is properly cited.

A solar pond has been fabricated to analyze the thermal behavior of it, in the climatic conditions of Moradabad, Uttar Pradesh. Sodium chloride $(\mathrm{NaCl})$ has been used to form a salt gradient for better performance, and a dark-colored (blackened) rigid surface bottom with $1 \mathrm{~mm}$ irregularities has been considered for trapping the heat in a good amount. A solar pond with a surface area of $2.56 \mathrm{~m}^{2}$ and a depth of $1 \mathrm{~m}$ has been filled with salty water of various densities to form three salty water zones (upper convective, nonconvective, and heat storage). A few investigations have been carried out to evaluate the thermal efficiencies of three different zones of the solar pond. An attempt is also made to improve the thermal performance of the salt gradient solar pond.

\section{Introduction}

On the Earth there is an abundant source of solar energy globally in which India has been counted for a good sunshine country. Since starting some of legendary contributors designed, modified, and developed many applications to utilize this source (sun) of energy for mankind. Various applications based on solar energy are solar water heater, solar cookers, solar stills, flat plate collectors, heat storage tank, solar thermal power plant, and solar pond for the purpose of water heating and other major requirements [1].

Water is an essential need of every living creature, which is used in a lot of manners or as a multipurpose supplement for a human being. There are some user-friendly and economical methods of water heating through utilization of solar energy. A solar pond is a body of water which is used to collect and store solar energy. The pond, either natural or man-made, contains salt water, which acts differently than fresh water. In a freshwater pond, sunlight inflowing the pond would heat up the water and by natural convection the heated water would rise to the top while the heavy cool water would sink to the bottom. Salt water, however, is heavier than fresh water and will not rise or mix by natural convection. This creates a larger temperature gradient within the pond which becomes hotter with depth - as hot as $200+\mathrm{F}^{\circ}$ at the bottom. Solar-powered ponds are basically free to operate. They do not add any utility bill because all the power required for operation is generated by a solar panel that uses free energy from the sun. The maintenance of a solar pond is generally simple and of low cost. Apart from this, the pond is powered by solar energy instead of electricity and does not contribute to the environmental harm associated with other power sources, particularly coal and nuclear power. Solar-generated electricity does not cause greenhouse gas emissions, which contribute to global climate change. They can be located anywhere that is suitable for building a pond, regardless of the distance to the nearest power outlet, as long as there is access to direct sunlight near the pond site.

There are four types of solar ponds (i) salt gradient solar ponds (ii) shallow solar pond (iii) salt-less convecting ponds and (iv) gel and viscosity stabilized pond. Fresh water forms a thin insulating surface layer at the top, and beneath it is the salt water. A salt gradient pond is the most common type of nonconvecting solar pond [2-7]. The initiative of creating artificial solar ponds was proposed first by Dr. Rudolph Bloch in 1954. A grave research effort was initiated in Israel by Tabor in 1958 by establishing the mechanism underlying solar ponds through a series of fundamental research papers. 
Though, it received a setback in 1966 when the fuel oil was competently cheaper than that available from solar ponds. It was later revived in 1973 [8]. In India, solar ponds are contributing to power generation by better utilization of solar energy (Table 1). Many other applications have been designed like a solar pond for water heating. Janjai et al. have developed a mathematical model for simulating the performance of a large-area plastic solar collector. The collector was installed and used to supply hot water to a hotel in Almeria, Spain [9]. Hull has made some nice efforts on this application. The author has experimentally tested by developing various models of salt gradient solar pond to know their thermal behavior through a mathematical model. Different ammonium salts were described for their thermophysical and optical properties and compared to $\mathrm{NaCl}[10-14]$.

Airnone-Martin and Martel have proposed the utilization of a salinity gradient solar pond (SGSP) technology to supply industrial process thermal energy. Potassium chloride $(\mathrm{KCl})$ was used to optimize the entire mining process, minimize environmental wastes, provide a safer, more economical extraction process, and reduce the need for conventional processing by crushing, indignant flotation [15]. Spitler has designed and developed a simulation tool for modeling the performance of a shallow pond as a supplemental heat rejecter in ground source heat pump systems through TRNSYS. The model has been validated by comparing simulation results to experimental data collected from two test ponds [16]. Ozek et al. investigated the performance of solar pond by introducing a transparent glass sheet as glazing and insulation to minimize the various heat losses [17]. Ouni et al. studied the response of a model of closed cycle salt gradient solar pond (CCSGSP) that ensures successful yearround operation. Heat and salt diffusion in the pond were taken into account and simulate the transient behavior of a SGSP [18].

El-Sebaii has investigated theoretically and experimentally a shallow solar pond integrated with a baffle plate. The energy balance equations were solved analytically using the elimination technique. It was found that the pond water temperature decreases with increasing vent area; therefore, the baffle plate should be used without vents with shallow depths of the upper water layer [19]. Solar ponds have been found to be effective when combined with a solar still for heat water applications. Velmurugana and Srithar have found that the optimum value of salinity in the minisolar pond was $80 \mathrm{~g} / \mathrm{kg}$ of water, integrated with a solar still. The theoretical and experimental analysis was carried out and found a good validation [20]. Karakilcik and Dincer developed a model to study the exergetic performance of the pond and its three zones in terms of exergy efficiencies which are then compared with the corresponding energy efficiencies. A data acquisition device was used to measure and record the temperatures hourly at various locations in the pond [21]. Bezir et al. experimentally tested the performance of a solar pond by using two additional reflectors focused on the top surface of the pond. An enhancement of $25 \%$ improvement in LCZ was found in comparison to a solar pond without reflector [22]. Garmana and Muntasserb have presented a mathematical model to study the factors affecting the size of
TABLE 1: Solar ponds in India [27].

\begin{tabular}{lccc}
\hline Location & Year & Area (sq.m) & Salt used \\
\hline Bhavnagar, Gujrat & 1971 & 1200 & Bittern \\
Pondicherry & 1980 & 100 & Sodium chloride \\
Bhavnagar, Gujrat & 1980 & 1600 & Bittern \\
IIT, Kharagpur & 1983 & 16 & Sodium chloride \\
IISc, Banglore & 1984 & 240 & Sodium chloride \\
Bhuj, Gujrat & 1990 & 6000 & Bittern \\
Masur, Karnatka & 1990 & 400 & Sodium chloride \\
\hline
\end{tabular}

solar pond to serve sufficient thermal load adequate to operate the desalination unit for the entire period of operation. The optimum thickness of the upper convecting zone was $0.3 \mathrm{~m}, 1.1 \mathrm{~m}$ for the nonconvecting zone, and $4 \mathrm{~m}$ in the lower convecting zone [23].

Saxena et al. studied and made a practical approach to identify the effect of the depth of water on the thermal performance of the salt gradient solar pond. The depth of water affects every parameter of the thermal performance of the pond [24]. Suárez et al. developed a fully coupled twodimensional numerical model to evaluate the effects of double-diffusive convection in the thermal performance and stability of a salt gradient solar pond [25]. Ould Dah et al. carried out experimental and numerical studies of the performance and the stability of $0.64 \mathrm{~m}^{2}$ minisolar pond. The results showed that the thermal insulation is particularly important in improving the efficiency of the mini pond. A singledimensional numerical model to predict the temperature and the salinity in the minipond was developed [26].

\section{Design Construction}

In this experimental work an insulated and double-glazed covered salt gradient solar pond having a surface area of $1.6 \mathrm{~m} \times 1.6 \mathrm{~m}$ and a depth of $1 \mathrm{~m}$ has been fabricated. The LCZ is $0.5 \mathrm{~m}$ high from the bottom of the pond with high-density brine. Approximately $0.1 \mathrm{~m}$ of fresh water on the top makes the UCZ containing light density brine, above which there is gradually decreasing density brine. This region performs the insulation, that is, keeps the stored energy in the bottom zone, called NCZ. This zone has a height of $0.3 \mathrm{~m}$. The total thickness of the side walls in which a glass wool is used for insulation is $8 \mathrm{~cm}$. The energy obtained from this system can be stored below the boiling point of the brine. Under the bottom of the pond a concrete with blocking with filling the gravel of $0.12 \mathrm{~m}$ thickness is fixed. The inner surface, which is made by $\mathrm{A} l$, is blackened to absorb and store the maximum sun's energy. The bottom surface area is $1.2 \mathrm{~m} \times 1.2 \mathrm{~m}$ and expanded to an exposed surface area to collect the heat energy in a large amount. The side walls of both the models were exposed at an angle of $110^{\circ}$ from the bottom surface. The total thickness of top glazing is $1.4 \mathrm{~cm}$ with a gap space of $1 \mathrm{~cm}$. The source of water supplying in solar pond is a tank of 300-liter capacity placed at a height of $5 \mathrm{~m}$ from the bottom surface level of the pond. A galvanized iron pipe (DIA- $2 \mathrm{~cm}$ with a length of $6 \mathrm{~m}$ ) is directly connected to the bottom of the pond via means of an open/close valve (Figure 1). 


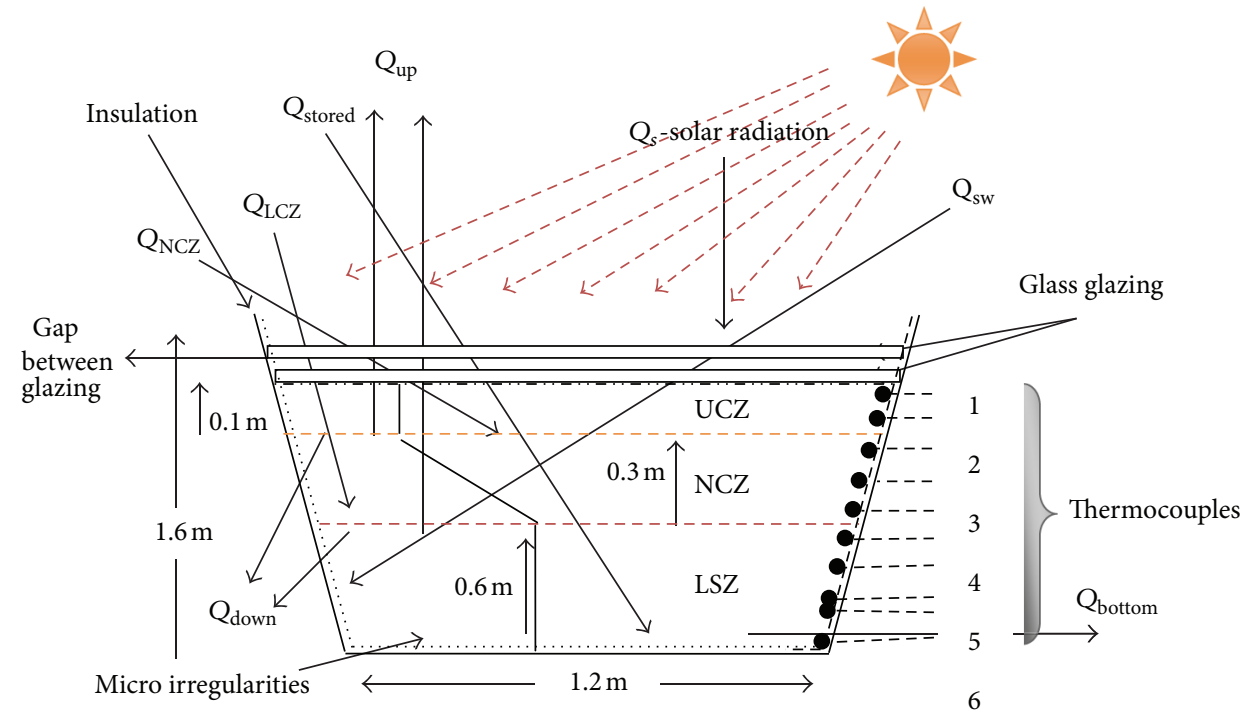

FIGURE 1: A schematic diagram of Shallow solar pond with rigid surface.

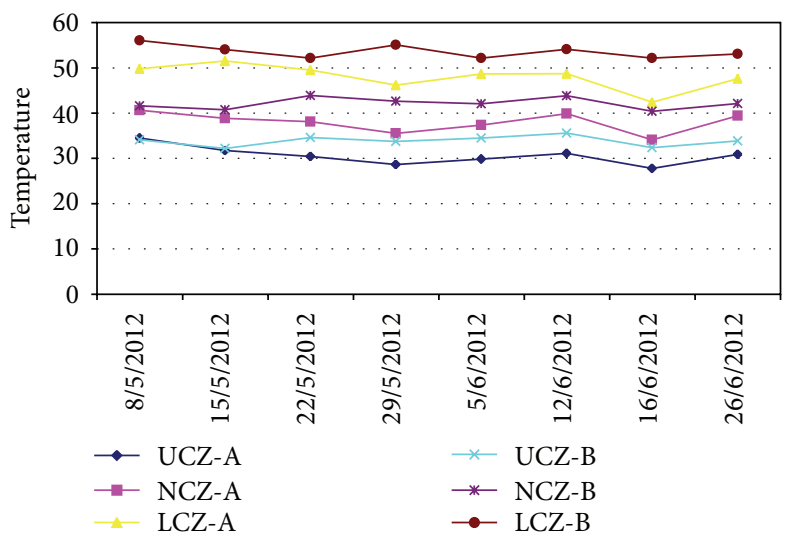

Figure 2: Performance curves of solar ponds "A" and "B".

\section{Performance Studies}

Two same size solar ponds have been constructed for performance testing; one is simply model " $\mathrm{A}$ " with single sheet $(1 \mathrm{~mm})$ glazing and flat surface walls and bottom. Both the ponds were constructed near a construction site allotted to make a swimming pool by the Development Authority of Moradabad. One solar pond model "B" with double-glazing and rigid-surface walls and bottom. Fresh water has been taken with a salt gradient to evaluate the performance of modified model. Sodium chloride has considered as a salt gradient for solar pond after studies of many salts used in solar ponds for water heating [28-30]. The quantity of $\mathrm{NaCl}$ (m $58.443 \mathrm{~g} / \mathrm{mol}$, appearance colorless, odorless, density $2.165 \mathrm{~g} / \mathrm{cm}^{3}, \mathrm{M} . \mathrm{P}-801^{\circ} \mathrm{C}, \mathrm{B} . \mathrm{P}-1413^{\circ} \mathrm{C}$, Solubility in water $356 \mathrm{~g} / \mathrm{L}$ ) has taken $4.7 \mathrm{~kg}$ for gradient zone of $0.30 \mathrm{~m}$ and a storage zone of $0.60 \mathrm{~m}$ [31]. The performance testing is carried out in the month of May and June 2012. The readings
TABLE 2: Temperature variation of three different zones of solar ponds "A" and "B".

\begin{tabular}{lccccccccc}
\hline Day & \multicolumn{3}{c}{$T_{\mathrm{amb}}$} & Radiation & \multicolumn{3}{c}{ Pond A $\left({ }^{\circ} \mathrm{C}\right)$} & \multicolumn{4}{c}{ Pond B $\left({ }^{\circ} \mathrm{C}\right)$} \\
$\mathrm{D} / \mathrm{M} / \mathrm{Y}$ & ${ }^{\circ} \mathrm{C}$ & $\mathrm{W} / \mathrm{m}^{2}$ & UCZ & NCZ & LCZ & UCZ & NCZ & LCZ \\
\hline $8 / 5 / 2012$ & 38 & 970 & 34.51 & 40.62 & 49.81 & 34.11 & 41.58 & 56.07 \\
$15 / 5 / 2012$ & 35 & 900 & 31.72 & 38.83 & 51.53 & 32.19 & 40.75 & 54.03 \\
$22 / 5 / 2012$ & 37 & 950 & 30.41 & 38.11 & 49.55 & 34.59 & 43.92 & 52.14 \\
$29 / 5 / 2012$ & 34 & 870 & 28.64 & 35.54 & 46.19 & 33.73 & 42.63 & 55.09 \\
$5 / 6 / 2012$ & 35 & 880 & 29.83 & 37.38 & 48.68 & 34.49 & 42.09 & 52.16 \\
$12 / 6 / 2012$ & 37 & 910 & 31.14 & 39.91 & 48.73 & 35.61 & 43.82 & 54.13 \\
$19 / 6 / 2012$ & 32 & 830 & 27.76 & 34.12 & 42.39 & 32.37 & 40.39 & 52.17 \\
$26 / 6 / 2012$ & 35 & 870 & 30.88 & 39.43 & 47.61 & 33.88 & 42.13 & 53.08 \\
\hline
\end{tabular}

have been taken in weekly step that is, for eight weeks as shown in Figure 2. A linear array of ten thermocouples with accuracy of $\pm 0.1^{\circ} \mathrm{C}$ was placed into the pond at different depth in different zones. A solari-meter "Surya-Mapi" has used for radiation measurement. The readings have taken to measure the variation in temperature in the different zones along the time, as shown in Table 2.

The energy balance equations are most essential key to know the thermal behavior of any system which has been used for similar applications [32-35]. The thermal efficiency of a thermodynamic system generally can be expressed as,

$$
\eta=\frac{Q_{\text {net }}}{Q_{\text {in }}},
$$

where net heat is the heat stored $(\Delta Q)$ in solar pond and

$$
\Delta Q=Q_{\text {in }}-Q_{\text {out }}=\left(Q_{s}+Q_{d}\right)-\left(Q_{\text {sw }}+Q_{\text {wta }}\right) \text {. }
$$


TABLE 3: Efficiencies variation of three different zones of solar ponds "A" and "B".

\begin{tabular}{lcccccc}
\hline Day & \multicolumn{3}{c}{ Efficiencies for pond A (\%) } & \multicolumn{5}{c}{ Efficiencies for pond B (\%) } \\
D/M/Y & UCZ & NCZ & LCZ & UCZ & NCZ & LCZ \\
\hline $8 / 5 / 2012$ & 2.09 & 4.31 & 11.21 & 3.12 & 7.83 & 18.82 \\
$15 / 5 / 2012$ & 1.83 & 3.98 & 7.87 & 2.97 & 7.02 & 13.61 \\
$22 / 5 / 2012$ & 1.51 & 3.71 & 7.53 & 2.06 & 6.32 & 11.98 \\
$29 / 5 / 2012$ & 1.03 & 2.92 & 6.24 & 1.98 & 5.96 & 10.73 \\
$5 / 6 / 2012$ & 1.81 & 3.69 & 7.79 & 2.83 & 6.73 & 13.37 \\
$12 / 6 / 2012$ & 2.03 & 4.45 & 11.63 & 3.43 & 8.42 & 18.54 \\
$19 / 6 / 2012$ & 0.91 & 2.11 & 6.17 & 1.71 & 5.04 & 9.01 \\
$26 / 6 / 2012$ & 0.98 & 39 & 47 & 1.84 & 5.41 & 10.31 \\
\hline
\end{tabular}

TABle 4: Performance of convective zones of both the models "A" and "B".

\begin{tabular}{ccccc}
\hline \multirow{2}{*}{ Zones } & \multicolumn{3}{c}{ Pond "A" maximum value of } & \multicolumn{2}{c}{ Pond “B” maximum value of } \\
& Temperature & Efficiency & Temperature & Efficiency \\
\hline $\mathrm{UCZ}$ & $34.51^{\circ} \mathrm{C}$ & $2.09 \%$ & $35.61^{\circ} \mathrm{C}$ & $3.43 \%$ \\
$\mathrm{NCZ}$ & $40.62^{\circ} \mathrm{C}$ & $4.45 \%$ & $43.92^{\circ} \mathrm{C}$ & $7.83 \%$ \\
$\mathrm{LCZ}$ & $51.53^{\circ} \mathrm{C}$ & $11.63 \%$ & $56.07^{\circ} \mathrm{C}$ & $18.82 \%$ \\
\hline
\end{tabular}

Solving (1) and (2) for the upper convective zone, nonconvective zone and lower connective zone then efficiencies for UCZ, NCZ and LCZ becomes,

$$
\begin{gathered}
\eta_{\mathrm{UCZ}}=1-\frac{\left[Q_{\mathrm{sw}}+Q_{\mathrm{wta}}\right]}{\left[Q_{s}+Q_{d}\right]}, \\
\eta_{\mathrm{NCZ}}=1-\frac{\left[Q_{\mathrm{sw}}+Q_{\mathrm{up}}\right]}{\left[Q_{N-\text { Solar }}+Q_{d}\right]}, \\
\eta_{\mathrm{LCZ}}=1-\frac{\left[Q_{b}+Q_{\mathrm{up}}+Q_{s}\right]}{Q_{L-\text { solar }}} .
\end{gathered}
$$

Using (3), the efficiencies for the different zones of solar pond has been obtained as given in Table 3 .

\section{Result and Discussion}

In the Table 1, the temperature variations of three different zones has been shown for two different models of solar pond. The variations in the ambient temperature were observed between a range of 32 to $38^{\circ} \mathrm{C}$, while the variations in solar radiations were noticed from 830 to $970 \mathrm{~W} / \mathrm{m}^{2}$. All the experiments have been conducted for performance evaluation of both the models of solar ponds in the climatic conditions of Moradabad -244001 and the readings were taken from 9:00 AM to 7:00 PM at a regular interval of one hour and shown on the average basis values of ambient conditions for the particular day.

The thermal performance of double glazed salt gradient solar pond has been investigated. Efficiencies are expressed (Figure 3) by using energy balance equations, for UCZ, NCZ and LCZ. The solar pond "A" was observed to get a maximum temperature $34.51^{\circ} \mathrm{C}$ (UCZ), $40.62^{\circ} \mathrm{C}(\mathrm{NCZ})$, and $51.53^{\circ} \mathrm{C}$ (LCZ), while the minimum temperature was observed to be $27.76^{\circ} \mathrm{C}$ (UCZ), $35.54^{\circ} \mathrm{C}(\mathrm{NCZ})$, and $42.39^{\circ} \mathrm{C}$ (LCZ). Apart

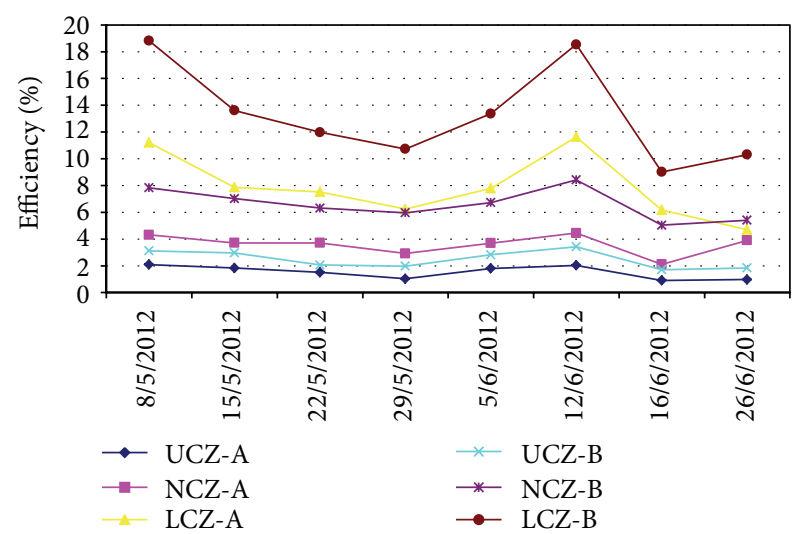

Figure 3: Efficiency curves of solar ponds "A" and "B".

from this, The solar pond "B" was observed to get a maximum temperature of $35.61^{\circ} \mathrm{C}$ (UCZ), $43.92^{\circ} \mathrm{C}(\mathrm{NCZ})$, and $56.07^{\circ} \mathrm{C}$ (LCZ), while the minimum temperature was observed to be $32.19^{\circ} \mathrm{C}$ (UCZ), $40.39^{\circ} \mathrm{C}(\mathrm{NCZ})$, and $52.14^{\circ} \mathrm{C}$ (LCZ). The results show that pond performance is affected strongly by the use of a double-glazing and inner rigid surface. Experimental data is used to obtain the efficiencies for all zones for a modified solar pond. Wind losses have been considered in performance calculations. It has been observed that modified solar pond "B" performed better by comparison to the simple solar pond "A" as given in Table 4.

It can be concluded that experimental investigations of two different salt-gradient solar ponds are carried out. Energy efficiencies of the UCZ, the NCZ, and the LCZ in the months of May and June 2012 are obtained. The lowest efficiencies were found in the UCZ because heat losses in air from the upper surface are the largest and therefore less energy is stored in the particular zone. The NCZ has higher efficiency than the UCZ because of lower heat losses in the NCZ. The highest efficiencies were found in the LCZ because a good amount of the energy in the LCZ of the pond was stored.

\section{Symbols/Notations}

SGSP: Salt gradient solar pond

$Q_{\text {in }}$ : Total energy input to solar pond

$Q_{\text {sw }}$ : Heat energy on side wall

$Q_{\text {wta }}$ : Heat transfer from water to air

$Q_{\text {bottom }}$ : Heat energy on bottom

$Q_{\mathrm{LCZ}}:$ Heat energy in lower convective zone

$Q_{\mathrm{NCZ}}$ : Heat energy in nonconvective zone

$Q_{U C Z}:$ Heat energy in upper convective zone

$Q_{\text {up }}: \quad$ heat above the zone

$Q_{\text {down }}:$ heat below the zone

$\eta$ : $\quad$ Efficiency

$H: \quad$ Solar radiation

$T, T_{\mathrm{amb}}$ : Temperature (ambient).

\section{References}

[1] R. C. Neville, Solar Energy Conversion, Elsevier, New York, NY, USA, 1995. 
[2] J. A. Duffle and W. A. Backman, Solar Engineering of Thermal Processes, Wiley, New York, NY, USA, 1974.

[3] H. P. Garg and J. Prakash, Solar Energy Fundamentals and Applications, McGraw-Hill, New York, NY, USA, 2006.

[4] S. P. Sukhatme, Solar Energy, Tata McGraw-Hill, New York, NY, USA, 3rd edition, 2006.

[5] J. R. Hull, K. V. Liu, W. T. Sha, J. Kamal, and C. E. Nielsen, "Dependence of ground heat loss upon solar pond size and perimeter insulation calculated and experimental results," Solar Energy, vol. 33, no. 1, pp. 25-33, 1984.

[6] J. R. Hull, D. L. Bushnell, D. G. Sempsrote, and A. Pena, "Ammonium sulfate solar pond: obser vations from small-scale experiments," Solar Energy, vol. 43, no. 1, pp. 57-64, 1989.

[7] J. R. Hull and C. E. Nielsen, "Steady-state analysis of the rising solar pond," Solar Energy, vol. 42, no. 5, pp. 365-377, 1989.

[8] H. Tabor, "Solar ponds," Solar Energy, vol. 27, no. 3, pp. 181-194, 1981.

[9] S. Janjai, A. Esper, and W. Mühlbauer, "Modelling the performance of a large area plastic solar collector," Renewable Energy, vol. 21, no. 3-4, pp. 363-376, 2000.

[10] J. R. Hull, "Computer simulation of solar pond thermal behavior," Solar Energy, vol. 25, no. 1, pp. 33-40, 1980.

[11] J. R. Hull, “Membrane stratified solar ponds," Solar Energy, vol. 25, no. 4, pp. 317-325, 1980.

[12] J. R. Hull, "Methods and means of preventing heat convection in a solar pond," US Patent [19], 1980.

[13] J. R. Hull, "Calculation of solar pond thermal efficiency with a diffusely reflecting bottom," Solar Energy, vol. 29, no. 5, pp. 385389, 1982.

[14] J. R. Hull, “Solar ponds using ammonium salts," Solar Energy, vol. 36, no. 6, pp. 551-558, 1986.

[15] C. T. Airnone-Martin and M.-A. Martel, "Salinity gradient solar pond technology applied to potash solution mining," in Environmental Improvements in Mineral Processing and Extractive Metallurgy, A. Sticbez, F. Vergara, and S. H. Castro, Eds., University of Concepcion, Edmundo Larenas, Chile, 2000.

[16] J. D. Spitler, "A Model for simulating the performance of a shallow pond as a supplemental heat rejecter with closed-loop ground-source heat pump systems," ASHRAE Transaction, vol. 106, part 2, 2000.

[17] N. Ozek, M. Kalkilik, and N. C. bezir, "A solar pond, odel with insulated and glass covered," Bulgarian Journal of Physics, vol. 27, no. 4, pp. 67-70, 2000.

[18] M. Ouni, A. Guizani, and A. Belghith, "Simulation of the control of a salt gradient solar pond in the south of Tunisia," Revue des Energies Renouvelables, pp. 175-182, 2001.

[19] A. A. El-Sebaii, "Thermal performance of a shallow solar-pond integrated with a baffle plate," Applied Energy, vol. 81, no. 1, pp. 33-53, 2005.

[20] V. Velmurugana and K. Srithar, "Solar stills integrated with a mini solar pond analytical simulation and experimental validation," Desalination, vol. 216, pp. 232-241, 2007.

[21] M. Karakilcik and I. Dincer, "Exergetic performance analysis of a solar pond," International Journal of Thermal Sciences, vol. 47, no. 1, pp. 93-102, 2008.

[22] N. C. Bezir, O. Dönmez, R. Kayali, and N. Özek, "Numerical and experimental analysis of a salt gradient solar pond performance with or without reflective covered surface," Applied Energy, vol. 85, no. 11, pp. 1102-1112, 2008.
[23] M. A. Garmana and M. A. Muntasserb, "Sizing and thermal study of salinity gradient solar ponds connecting with the MED desalination unit," Desalination, vol. 222, no. 1-3, pp. 689-695, 2008.

[24] A. K. Saxena, S. Sugandhi, and M. Husain, "Significant depth of ground water table for thermal performance of salt gradient solar pond," Renewable Energy, vol. 34, no. 3, pp. 790-793, 2009.

[25] F. Suárez, S. W. Tyler, and A. E. Childress, "A fully coupled, transient double-diffusive convective model for salt-gradient solar ponds," International Journal of Heat and Mass Transfer, vol. 53, no. 9-10, pp. 1718-1730, 2010.

[26] M. M. Ould Dah, M. Ouni, A. Guizani, and A. Belghith, "The influence of the heat extraction mode on the performance and stability of a mini solar pond," Applied Energy, vol. 87, no. 10, pp. 3005-3010, 2010.

[27] G. R. R. Murthy and K. P. Pandey, Solar Ponds: A Perspective from Indian Agriculture, Department of Agricultural and Food Engineering, Indian Institute of Technology, Kharagpur, India, 2000.

[28] H. Lu, J. C. Walton, and A. H. P. Swift, "Desalination coupled with salinity-gradient solar ponds," Desalination, vol. 136, no. $1-3$, pp. 13-23, 2001.

[29] H. Kurt, M. Ozkaymak, and A. K. Binark, "Experimental and numerical analysis of sodium-carbonate salt gradient solarpond performance under simulated solar-radiation," Applied Energy, vol. 83, no. 4, pp. 324-342, 2006.

[30] M. C. Giestas, H. L. Pina, J. P. Milhazes, and C. Tavares, "Solar pond modeling with density and viscosity dependent on temperature and salinity," International Journal of Heat and Mass Transfer, vol. 52, no. 11-12, pp. 2849-2857, 2009.

[31] R. Peter and T. H. Short, "Salt gradient solar ponds: research progress in Ohio and future prospects," in Proceedings of the 6th International Symposium on salt, vol. 2, Salt Institute, 1983.

[32] S. C. Sharma and A. Tiwari, "Performance enhancement of shallow solar pond by system Modification," International Journal on Emerging Technologies-, vol. 1, no. 1, pp. 92-96, 2010.

[33] H. C. Bryant and I. Colbeck, "A solar pond for London?" Solar Energy, vol. 19, no. 3, pp. 321-322, 1977.

[34] M. N. A. Hawlader, "The influence of the extinction coefficient on the effectiveness of solar ponds," Solar Energy, vol. 25, no. 5, pp. 461-464, 1980.

[35] H. Rubin and G. A. Bemporad, "The advanced solar pond (ASP): basic theoretical aspects," Solar Energy, vol. 43, no. 1, pp. 35-44, 1989. 


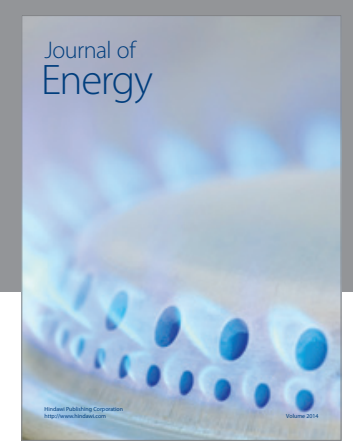

Journal of

Industrial Engineering
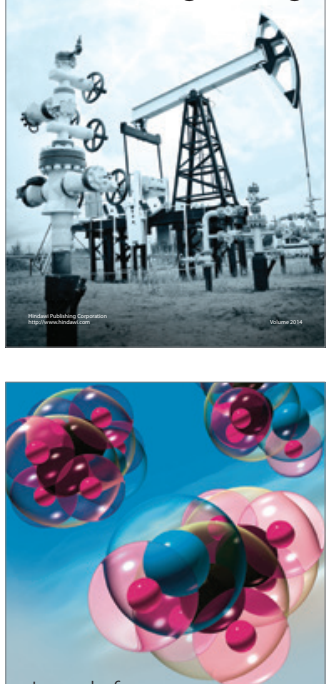

Fuels
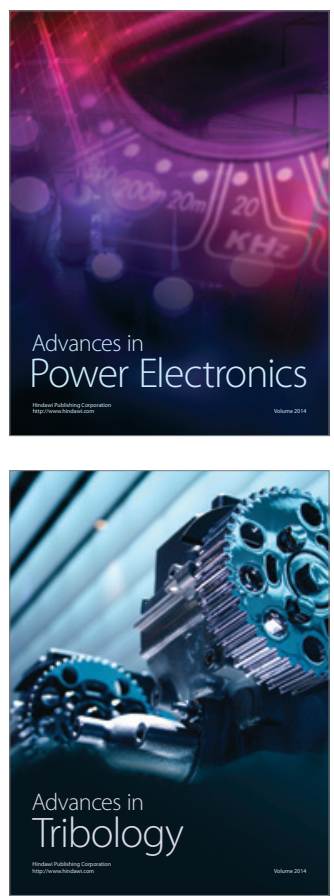

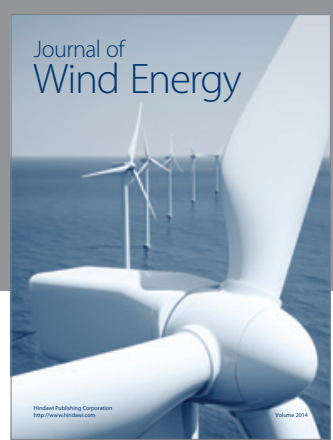

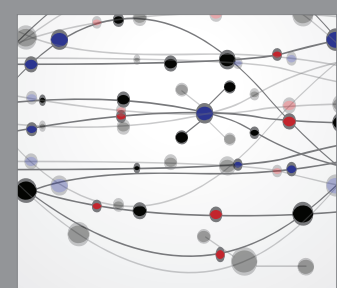

The Scientific World Journal

Submit your manuscripts at http://www.hindawi.com

Journal of

Structures
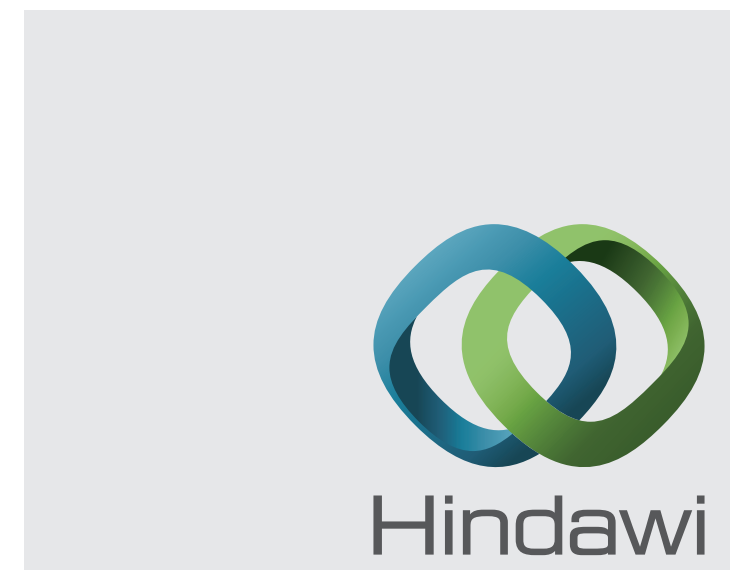

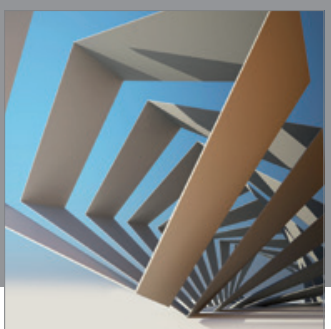

Rotating

Machinery
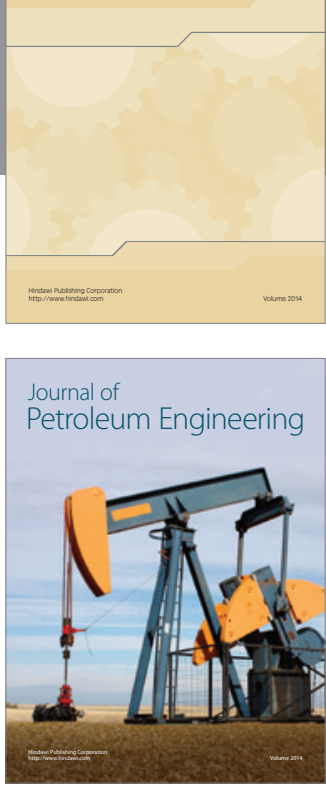

Journal of

Solar Energy
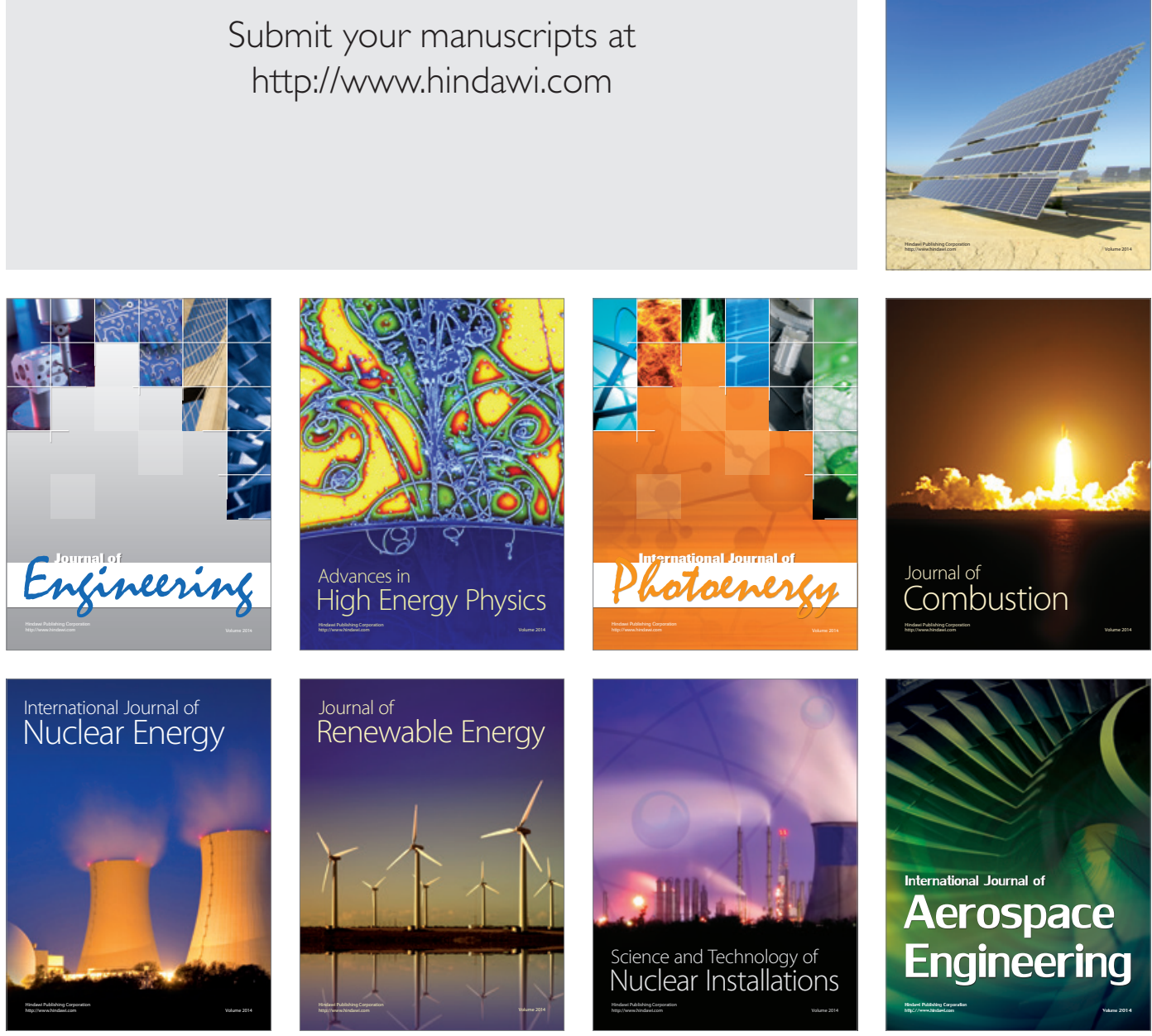